\title{
Zika virus infection and pregnancy
}

\author{
INFECÇÃo PELO VÍRUS ZIKA E GRAVIDEZ \\ Authorship: Associação Médica Brasileira \\ Final Draft: March 18, 2016 \\ Participants: Ricardo Simões ${ }^{1,2}$, Renata Buzzini² ${ }^{2}$, Wanderley Bernardo², Florentino Cardoso², Antônio Salomão ${ }^{1}$, \\ Giovanni Cerri²
}

${ }^{1}$ Federação Brasileira das Associações de Ginecologia e Obstetrícia (Febrasgo)

${ }^{2}$ Guidelines Project, Associação Médica Brasileira

The Guidelines Project, an initiative of the Brazilian Medical Association, aims to combine information from the medical field in order to standardize procedures to assist the reasoning and decision-making of doctors.

The information provided through this project must be assessed and criticized by the physician responsible for the conduct that will be adopted, depending on the conditions and the clinical status of each patient.

\section{Description of the eVIDENCE COLECTION METHOD}

The literature review of scientific articles in this guideline was held in the databases Medline, Embase and Cochrane, using the terms (MeSH terms) individually or grouped, structured according to P.I.C.O. ("Patient", "Intervention", "Control" and "Outcome") methodology. After carefully reading the titles and abstracts, only articles containing relevant information to the components of P.I.C.O. were included. The studies were analyzed for relevance and level of evidence according to the Oxford Centre for Evidence Based Medicine ${ }^{1}(\mathbf{D})$ table.

\section{Grade of Recommendation AND StREngth of EVIDENCE}

A. Experimental or observational studies of higher consistency.

B. Experimental or observational studies of lower consistency.

C. Case reports/non-controlled studies.

D. Opinions without critical evaluation, based on consensus, physiological studies, or animal models.

\section{Objective}

This guideline is intended for physicians, nurses, public health officials and patients at risk of Zika virus infection, with the purpose of assessing the effects on the period of pregnancy and postpartum.

\section{Conflict of interest}

No conflict of interest was declared by the participants in the development of this guideline.

\section{INTRODUCTION}

The Zika virus, first isolated in 1947 in rhesus monkeys in the Zika forest in Uganda, is an arbovirus, member of the Flaviviridae family and the flavivirus genus. First found in humans in Nigeria in 1954, for 50 years the virus was described as a cause of sporadic human infections in Africa and Asia, until in 2007 an epidemic took place in Micronesia. ${ }^{2,3}(\mathbf{C})$ More recently, outbreaks were identified in 15 different islands of Polynesia. The Ministry of Health of Brazil, as verified by the data provided by the Live Births Information System (SINASC), has recorded substantial increase in the number of cases of microcephaly (Chart 1) in the country after a high incidence of infection. The clinical features and natural history of Zika infection are based on a limited number of case reports; however, it is clear that vertical transmission of the virus can occur during pregnancy, as seen in a series of reports of cases of microcephaly among children whose mothers were infected with Zika virus. ${ }^{4,5}(\mathbf{C})^{6}(\mathbf{D})$

According to an epidemiological report for monitoring cases of microcephaly in Brazil, until February 6, 2016, $75.8 \%$ of the cases reported $(3,852 / 5,079)$ remained under investigation, of which $62.5 \%(n=3,174)$ were reported in 2015 and $37.5 \%(n=1,905)$ in $2016 .^{7}(\mathbf{D})$ According to the final classification, $24.2 \%$ of the total cases were investigated and classified and, of these, $15.1 \%(n=765)$ were discarded for the presence of microcephaly and/or changes in the central nervous system suggestive of congenital infection. Of the remaining, 9.1\% $(462 / 5,079)$ were confirmed according to specific protocol definitions (Charts 1 and 2, and Annex) and, of these, only $8.9 \%$, i.e., 41 out of 462 , were confirmed as associated with infection with Zika virus by 
clinical and laboratory testing following the criteria for diagnostic confirmation ${ }^{8,9}(\mathbf{D})$ (compared to the previous epidemiological week, in which 17 cases were confirmed, 24 new cases with identification of Zika virus were confirmed in laboratory tests, totaling 41 cases). As for cases progressing to miscarriage or postpartum death, $1.8 \%$ of the total $(91 / 5,079)$ were recorded. According to the classification, $64.8 \%$ (59/91) remained under investigation; 8.8\% (8/91) were investigated and discarded according to the case definition, and 26.4\% (24/91) were investigated and confirmed for microcephaly and/or changes in the central nervous system $(\mathrm{CNS})^{7}{ }^{7}$ (D) A recent epidemiological report states that until February 20, 2016 (epidemiological week SE 07/2016), 5,640 cases of microcephaly were reported and of these only 583 were confirmed for either microcephaly or CNS abnormalities suggestive of congenital infection. ${ }^{9}(\mathbf{D})$

\section{CHART 1 Definition of microcephaly.}

In newborns at term, the reference value used to define microcephaly is a head circumference $\leq 32 \mathrm{~cm}$ at birth, according to the curves of the World Health Organization (WHO). For newborns preterm, head circumference below minus 2 standard deviations (SD), according to Fenton curve.

\section{CHART 2 Definition of congenital infection with Zika virus.}

Presence of typical changes indicative of congenital infection such as intracranial calcifications, dilation of cerebral ventricles or changes in posterior fossa, and other clinical signs found by any imaging method, or identification of Zika virus in laboratory tests.

Therefore, as noted, despite the increase seen in the number of cases of newborns diagnosed with microcephaly, the total number of cases that are actually associated with Zika virus infection is not known. Also, aspects of a cause and effect relation between Zika virus infection and microcephaly, diagnosis, treatment, knowledge of the viremic period, and factors related to increased risk to the fetus, including recognition of the gestation period that is more susceptible to the virus and monitoring of the newborn, are not clarified. Thus, in order to build a robust knowledge framework of the occurrence of this infection among pregnant women and its effect on the fetus, prospective studies with adequate follow-up are needed.

In view of the aspects explained above, the development of clinical guidelines regarding the knowledge acquired to date on an association between infection with Zika virus and its effects on pregnancy and childbirth is imperative in order to delimit and advise on panoramas related to preconception counseling, prenatal, labor, postpartum and newborn care.

\section{Objectives}

Prepare a clinical guideline that includes, in light of current scientific evidence available, answers to clinical questions structured according to the components of P.I.C.O. (P [Patient]; I [ntervention]; C [Comparison]; O [Outcome]).

\section{Methods}

The evidence used to evaluate the occurrence of infection with Zika virus during pregnancy was obtained according to the following steps: preparation of the clinical question, structuring of the question, search for evidence, critical evaluation and selection of evidence.

\section{Structured questions}

1. During pregnancy, what is the association between Zika virus and microcephaly?

2. What is the association between Zika virus and Guillain-Barré syndrome? Is it different during pregnancy? Can it affect the fetus?

3. What are the symptoms in pregnant women with suspected Zika virus infection? Are they different than in the general population?

4. How to make a definitive diagnosis of Zika virus infection during pregnancy?

5. What is the treatment for Zika virus infection during pregnancy?

6. How is follow-up of pregnant women infected with Zika virus done?

7. What are the precautions to be taken with babies born from pregnant women with a history of Zika virus infection?

8. What is the care required for newborns diagnosed with microcephaly during pregnancy?

\section{Databases consulted}

Primary scientific databases consulted were Medline, Embase and Cochrane. A manual search from the references of narrative reviews was also performed. See in Chart 3 the databases consulted and respective search strategies. Chart 4 displays the number of studies retrieved from each scientific database until 2/23/16.

CHART 3 Primary databases consulted and search strategy.

Medline: (Zika Virus OR Virus, Zika OR ZIKV OR Flavivirus OR Flaviviruses OR Arbovirus, Group B OR Arboviruses, Group B OR Group B Arbovirus OR Group B Arboviruses) AND (Pregnancy OR Pregnancies OR Gestation).

Embase: 'pregnancy'/exp AND ‘flavivirus'/exp.

Cochrane: (Zika Virus AND Pregnancy). 


$\begin{aligned} & \text { CHART } 4 \text { Number of studies retrieved by primary } \\
& \text { database. }\end{aligned}$
\begin{tabular}{ll} 
Database & Number of studies \\
\hline PubMed-Medline & 173 \\
\hline Embase & 171 \\
\hline Cochrane & 0
\end{tabular}

Inclusion criteria for studies retrieved

Selection of studies, assessment of titles and abstracts obtained from the search strategy in the consulted databases was conducted by two researchers (R.S.S. and W.M.B.) with skills in the preparation of systematic reviews, both independent and blinded, strictly observing the inclusion and exclusion criteria previously established. All potentially relevant studies were identified. Whenever the title and the summary were not enlightening, researchers sought the full article.

\section{Study design}

Case reports, case series and guidelines were included in the evaluation. Narrative reviews were included in the reading with the purpose of retrieving reference that could have been lost in the initial search strategy. Physiological reports or studies based on animal models, as well as those unrelated with our P.I.C.O. components, were not included. Only articles whose full text was available were included in the guideline.

\section{P.I.C.0. components}

- Patient: Pregnant women, patients diagnosed with Guillain-Barré syndrome, newborns of pregnant women with a history of Zika virus infection, newborns diagnosed with microcephaly during pregnancy. In all cases, patients with a established or suspected diagnosis of Zika virus infection were considered.

- Intervention: Diagnosis, treatment.

- Comparison.

- Outcome: Microcephaly, Guillain-Barré syndrome.

\section{Language}

We included studies available in Portuguese, English, French or Spanish.

\section{Studies retrieved}

After entering the search strategy in the primary databases (PubMed-Medline, Embase and Cochrane), the assessment of titles and abstracts led to the selection of 288 studies.

\section{Evidence selected}

The studies considered for full text reading were assessed according with set inclusion and exclusion criteria, P.I.C.O., language and availability of the full text (Figure 1 - Annex).

\section{DURING PREgnanCY, What IS THE ASSOCIATION BETWEEN ZIKA VIRUS AND MICROCEPHALY?}

In Brazil, a possible association between Zika virus infection during pregnancy and microcephaly has been under investigation since October 2015 when the Ministry of Health reported an increase in the number of cases of microcephaly close to 20 times that previously reported (approximately 0.5 cases for each 10,000 live births) after an outbreak of this virus. ${ }^{10,11}(\mathbf{D})$ This report made the Pan American Health Organization (PAHO) publish a warning about the increased occurrence of microcephaly in Brazil. ${ }^{12}(\mathbf{D})$ In the same year, the PAHO reported viral genome identification using reverse transcriptase technique followed by polymerase chain reaction in real time (RT-PCR) in amniotic fluid samples from two pregnant women whose fetuses had microcephaly identified during ultrasonography performed during prenatal monitoring. In addition, Zika virus RNA was identified in various tissues, including the brain, of a child with microcephaly who died in the immediate neonatal period. ${ }^{13}(\mathbf{D})$ These events led to new alerts issued by the Ministry of Health of Brazil, the European Centre for Disease Prevention and Control (ECDC), and the US Center for Disease Control and Prevention (CDC) on a possible association between microcephaly and the recent outbreak of Zika virus infection. ${ }^{14,15}$ (D) The first case of congenital malformations (microcephaly) found in the European Union and which is associated with infection by Zika virus during pregnancy, was published in February 2016. ${ }^{4}$ (C) The report was that of a case of fetus with microcephaly, whose mother had Zika virus infection in the first trimester of pregnancy after a trip to $\operatorname{Brazil}^{4}(\mathbf{C})$

The sudden increase in the number of children born with microcephaly associated with brain damage typically seen in congenital infections in regions where newly circulating virus outbreak occurred, as well as the identification of viral genome in amniotic fluid, are suggestive of a possible causal relationship. Also, neurotropism of this virus is known since 1952, found in studies using guinea pigs. ${ }^{16}(\mathbf{C})^{17}(\mathbf{D})$ However, some questions are necessary to understand and validate the relationship of cause and effect. The first point refers to the prevalence of the historical birth of infants with malformations of the central ner- 


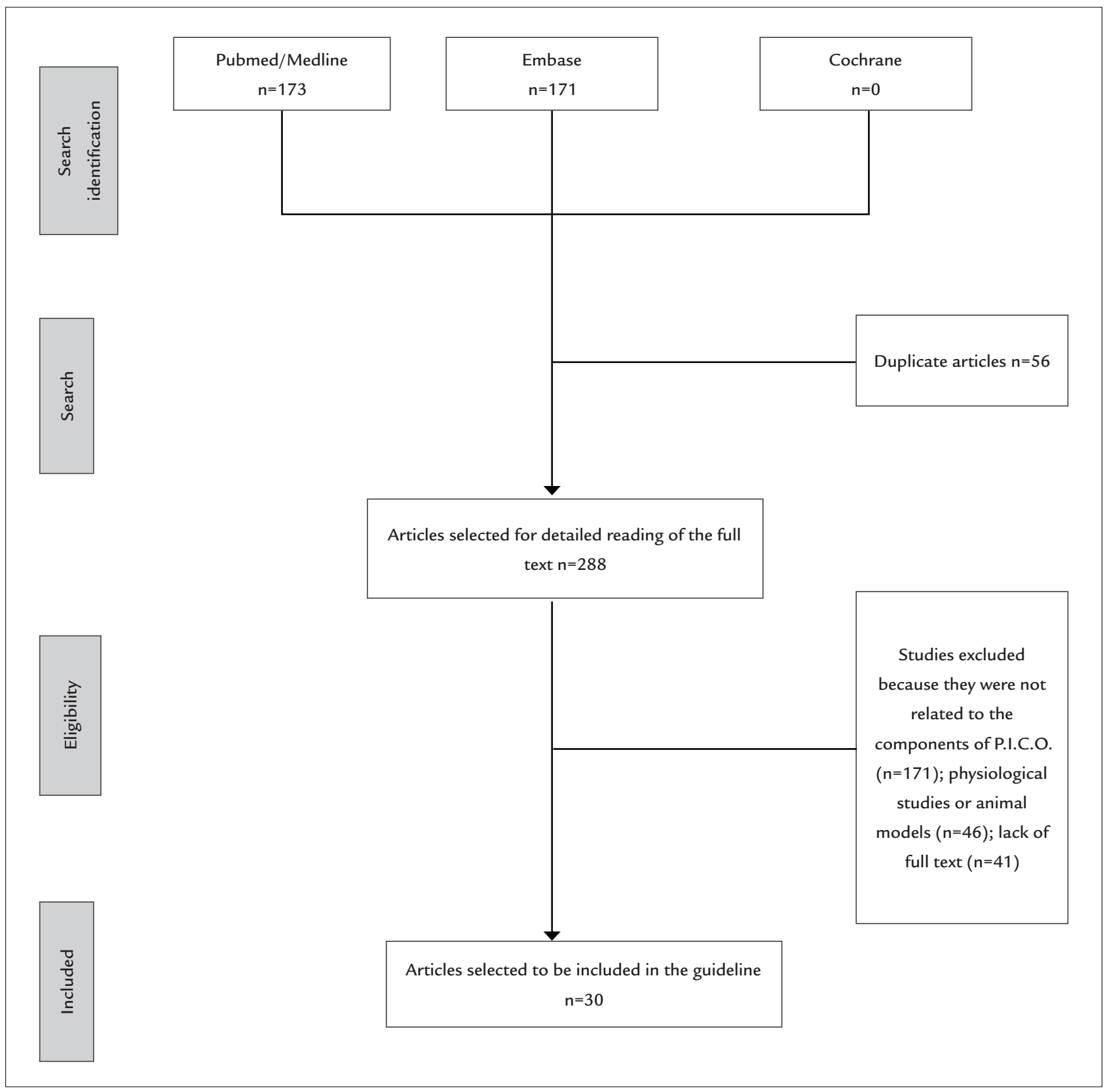

FIGURE 1 Flowchart for study selection.

vous system in Brazil, which is about five cases per 100,000 live births, less than the estimates recently made of 10 to 20 cases per 100,000 live births. This may indicate the occurrence of underreporting of microcephaly in the country. ${ }^{18}(\mathbf{D})$ Thus, any active search for this congenital malformation would be able to increase its prevalence, with a clear excess in the number of cases. Another point related to the increase in the number of cases would be the change in diagnostic criteria, accepting as microcephaly cases of head circumference measuring less than $33 \mathrm{~cm}$, possibly explaining a situation of over-diagnosis. Another relevant question, since the infection Zika virus in newborns and pregnant women were not confirmed by laboratory tests at first, is that the history of nonspecific rash referred to during pregnancy is subject to recall bias and may have incurred potential misclassification regarding exposure to Zika virus. Regardless of any controversies to confirm, or not, the role of Zika virus in the genesis of cases of microcephaly, measures to prevent infection with this virus are necessary and unquestionable. 
Recommendation

The magnitude of the risk that infection with Zika virus occurred during pregnancy will result in birth defects remains unknown to date. The studies reported (case reports) presented significant methodological problems regarding selection of the pregnant women, definition of the outcome (microcephaly) and definition of exposure (lack of adequate serologic tests because of the similarity between the Dengue virus and Zika virus, and identification of the genome virus by RT-PCR hindered by the short period in which the virus is present in the blood or other tissues). Thus, further evidence arising from prospective epidemiological studies is needed to establish a causal link between Zika virus infection and congenital malformations in the central nervous system.

\section{What is the association between zika VIRUS AND GUILLAIN-BARRÉ SYNDROME? IS IT DIFFERENT DURING PREgNANCY? CAN IT AFFECT THE FETUS?}

Guillain-Barré syndrome (GBS) is a neurological disease that consists of an acute autoimmune inflammatory demyelinating polyneuropathy, whose basic pathophysiological process is not completely known. This is the leading cause of widespread flaccid paralysis in the world with an annual incidence of 1 to 4 cases per 100,000 inhabitants. ${ }^{19}(\mathbf{D})$ It typically appears in two to three weeks after nonspecific viral infection. The occurrence of neurological syndromes after infectious processes by dengue virus and chikungunya is described since the late 1960s, and with Zika virus infection since 2007, especially after the outbreaks in Micronesia and in French Polynesia. ${ }^{2}(\mathbf{C})$

In the primary databases consulted, there is only one case report occurred in French Polynesia in which GBS was diagnosed in a patient infected with Zika virus. The report showed the first case of GBS manifested seven days after febrile illness characterized as Zika virus infection based on serological results. ${ }^{20}(\mathbf{C})$

The association between Zika virus infection and Guillain-Barré syndrome still needs confirmation through analytical studies. One factor that hinders greater understanding about this association in Brazil is the lack of epidemiological data specific for this syndrome.

\section{Recommendation}

Investigations regarding an association between Zika virus infection and Guillain-Barré syndrome are still ongoing in the affected countries.

\section{What ARE THE SYMPTOMS IN PREgNANT WOMEN WITH SUSPECTED ZIKA VIRUS INFECTION? ARE THEY DIFFERENT THAN IN THE GENERAL POPULATION?}

It is estimated that $80 \%$ of people infected by Zika virus do not develop clinical manifestations as seen from epidemiological studies. However, when there is clinical manifestation, the main associated signs and symptoms are usually: sudden fever (sometimes absent); pruritic maculopapular rashes that can affect the face, trunk, limbs, palms and soles; non-purulent conjunctivitis; fatigue and myalgia; and joint pain in the extremities (wrist/ankle), often associated with edema. Other unspecific manifestations that may be reported are headache, retro-orbital and abdominal pain, diarrhea, vomiting, constipation and cough. ${ }^{3,4,21-24}(\mathbf{C})$ No sign is pathognomonic of infection with Zika virus.

Studies specifically evaluating the population of pregnant women infected by Zika virus are rare in the literature. However, a case series conducted in Brazil revealed that $72.4 \%(n=21)$ of the women experienced rash; $44.8 \%(n=13)$ had fever; $37.9 \%(n=11)$ had arthralgia; with headache in $17.2 \%$, and pruritus in $13.8 \%$. All pregnant women denied ophthalmologic manifestations. ${ }^{23}(\mathbf{C})$ In this study, other causes for the symptoms were excluded such as infection with cytomegalovirus, rubella, herpes virus, syphilis, toxoplasmosis and HIV. However, the major problem in this assessment would be the sample, which was made for convenience of women who showed signs and symptoms suggestive of infection Zika virus. Another point of great limitation for the interpretation of these results is the lack of statistical analysis, which would make it impossible to claim that the percentages or findings are exclusive to this population or if they can be extrapolated to all presumed infections with Zika virus. ${ }^{23}(\mathbf{C})$

\section{Recommendation}

To date, there is no full recognition of the clinical manifestations of infection caused by Zika virus in specific populations, such as pregnant women, since information derive from isolated case reports or series of cases in epidemic situations.

When present, the signs and symptoms are characterized by intermittent fever, non-purulent conjunctival hyperemia, pruritic maculopapular rash, arthralgia, myalgia and headache. 


\section{How to make a definitive diagnosis of ZIKA VIRUS INFECTION DURING PREGNANCY?}

Information about laboratory abnormalities during Zika virus infection are scarce in the literature, but leukopenia, thrombocytopenia, elevation of serum lactate dehydrogenase, and elevated markers of inflammatory activity such as C-reactive protein are reported. ${ }^{25,26}(\mathbf{C})$

A limiting factor that hinders a direct biological diagnosis, especially using molecular biology techniques, and may be related to false-negative results is that the Zika virus genome is made of ribonucleic acid (RNA), which is very fragile. The Zika virus can be isolated in cell cultures such as Vero cells, and its identification is done by indirect immunofluorescence. However, this technique is reserved for specialized laboratories. ${ }^{24}(\mathbf{C})$

Immunoenzymatic test (ELISA) for detection of immunoglobulins (IgG and IgM) and plaque-reduction neutralization test (PRNT) can be used. But there is a problem related to serological testing, which is the possibility of cross-reactivity as a result of previous infection by other flavivirus. ${ }^{4}(\mathbf{C})^{27}(\mathbf{D})$

The identification of viral genome by reverse transcriptase followed by real-time polymerase chain reaction (RT-PCR) from RNA directly extracted from the patient's serum and preferably collected up to the sixth day of the disease is the most sensitive and specific method for diagnosis of Zika virus infection. ${ }^{4,29}(\mathbf{C})^{28}(\mathbf{D})$ One must be aware of the possibility of false-negative results since, contrary to what is observed for other viruses, the restricted circulation of Zika virus has limited the knowledge about its actual genetic diversity.

\section{Recommendation}

To date, there are no commercial tests allowing serological diagnosis of Zika virus infection. The diagnosis of acute infection can be done by RT-PCR within a week from the onset of symptoms.

\section{What is the treatment for Zika virus INFECTION DURING PREGNANCY?}

There are no vaccines, preventive drugs, or specific antiviral treatments for Zika virus infection. Treatment is generally supportive and may include rest, hydration, nonsteroidal anti-inflammatory drugs or non-salicylic analgesics used in an individual basis after careful clinical evaluation. Given that clinical diagnosis is not conclusive, and even serological analysis may fail, the use of salicylates as analgesics should be discouraged because of the increased risk of hemorrhagic events described in hemorrhagic syndromes, as in other flavivirus infections.
The pathophysiology of cutaneous manifestations remains unknown, but antihistamines can benefit patients, acting as a sedative and not as an agent to treat the cause of the itching. ${ }^{30}(\mathbf{D})$

Recommendation

There is no specific treatment for infection with Zika virus. In symptomatic cases, care is based primarily on relieving the pain and lowering the fever, with antihistamines for pruritic eruptions. Treatment with nonsteroidal anti-inflammatory drugs or salicylates is discouraged due to the potentially increased risk of hemorrhagic syndrome.

\section{HOW IS THE FOLLOW-UP OF PREGNANT WOMEN INFECTED WITH ZIKA VIRUS DONE?}

Pregnant women tested positive for Zika virus infection (identified by RT-PCR or detection of IgM/IgG immunoglobulins) should be referred for high-risk prenatal care. There are no studies with appropriate design plan for the monitoring of pregnant women diagnosed with Zika virus aiming to assess prognosis or quality of life. Howev$\mathrm{er}$, if the fetal ultrasound examination is normal in women tested positive for Zika virus infection, both physician and patient should considerer scheduling ultrasounds serially every 3 to 4 weeks to monitor fetal anatomy and growth. ${ }^{31}(\mathbf{D})$

\section{Recommendation}

Serial fetal ultrasound every 3 to 4 weeks should be considered for pregnant women diagnosed with Zika virus infection to monitor fetal anatomy and growth.

\section{What are the precautions to be taken WITH BABIES BORN FROM PREGNANT WOMEN WITH A HISTORY OF ZIKA VIRUS INFECTION?}

Targeted diagnostic tests to identify Zika virus infection should be recommended for infants with microcephaly or intracranial calcifications born to women who traveled to or lived during pregnancy in areas where the virus circulates; or children born to mothers with positive or inconclusive results for Zika virus infection. A newborn is considered congenitally infected if viral RNA or antigen is identified in any samples presented for analysis, including testing of amniotic fluid or placental cord blood analysis. For newborns with laboratory evidence of possible congenital infection with Zika virus, further clinical evaluation and monitoring are recommended. In these cases, clinical history, physical examination including measurement of head circumference, length, weight and assessment of gestational age, are needed. Neurolog- 
ical abnormalities, skin rashes, dysmorphic features, splenomegaly and hepatomegaly should be evaluated. Ophthalmologic evaluation and otoacoustic emission examination should be conducted before hospital discharge or within a month after birth. ${ }^{32}(\mathbf{C})$

For children with microcephaly or intracranial calcifications, additional evaluation should include consultation with a pediatric neurologist. Test for other congenital infections such as syphilis, toxoplasmosis, rubella, cytomegalovirus and herpes simplex virus infections should be requested. Genetic causes should also be investigated, as well as maternal substance abuse, exposure to ionizing radiation, use of teratogenic agents and infections in general. ${ }^{33}(\mathbf{D})$

\section{Recommendation}

There are no studies with appropriate design aimed to evaluate proper care that should be given to newborns of pregnant women with a history of Zika virus infection. The main objective of the investigation is to confirm the diagnosis of infection in the newborn. Further clinical evaluation and monitoring are recommended for children with laboratory evidence of possible congenital Zika virus infection. Infants diagnosed with microcephaly, according to the definition of suspected cases (Chart 1 - Annex), should be referred for follow-up in a pediatric neurology service.

\section{WHAT IS THE CARE REQUIRED FOR NEWBORNS DIAGNOSED WITH MICROCEPHALY DURING PREGNANCY?}

Because of the range of differential diagnoses ranging from other congenital infections, genetic abnormalities, familial microcephaly, and more, it is imperative to confirm the diagnosis of Zika virus infection in microcephalic newborns. Thus, careful history should answer the following questions: maternal history (intrauterine infections, placental insufficiency, pre-existing maternal diseases); maternal exposure to ionizing radiation or potentially teratogenic agents (drugs, alcohol, smoking, etc.); drugs used during pregnancy; presence of skin rash and other signs and symptoms of infection during pregnancy; and family history. Complete physical examination of the newborn should be performed, with measurement of head circumference, length, weight and gestational age assessment, also including a detailed neurological examination. Ophthalmologic evaluation within 1 month after birth is recommended, including retinal assessment, since abnormal ophthalmologic findings such as macular abnormalities and optic nerve disorders are reported in microcephalic children with possible congenital infection with Zika virus. ${ }^{23,34}(\mathbf{C})$ The mother must also be tested for Zika virus infection, in case this was not done during pregnancy.

\section{Recommendation}

Zika virus infection should be confirmed in newborns with microcephaly or intracranial calcifications. For those who tested negative, other causes should be investigated and treated as indicated. ${ }^{33}(\mathbf{D})$ Children diagnosed with microcephaly should be referred for follow-up in a pediatric neurology service.

\section{References}

1. Levels of Evidence and Grades of Recommendations - Oxford Centre for Evidence-Based Medicine. [cited 2008 Jun]. Available from: http://www cebm.net/oxford-centre-evidence-based-medicine-levels-evidence-march-2009/.

2. Duffy MR, Chen TH, Hancock WT, Powers AM, Kool JL, Lanciotti RS, et al Zika virus outbreak on Yap Island, Federated States of Micronesia. N Engl J Med. 2009; 360(24):2536-43.

3. Fagbami AH. Zika virus infections in Nigeria: virological and seroepidemiological investigations in Oyo State. J Hyg (Lond). 1979; 83(2):213-9.

4. Mlakar J, Korva M, Tul N, Popović M, Poljšak-Prijatelj M, Mraz J, et al. Zika virus associated with microcephaly. N Engl J Med. 2016. [Epub ahead of print]

5. Rubin EJ, Greene MF, Baden LR. Zika virus and microcephaly. N Engl J Med. 2016. [Epub ahead of print]

6. Schuler-Faccini L, Ribeiro EM, Feitosa IM, Horovitz DD, Cavalcanti DP, Pessoa A, et al; Brazilian Medical Genetics Society-Zika Embryopathy Task Force. Possible association between Zika virus infection and microcephaly - Brazil, 2015. MMWR Morb Mortal Wkly Rep. 2016; 65(3):59-62.

7. Monitoramento dos casos de microcefalia no Brasil. Informe Epidemiológico $\mathrm{N}^{\circ} 12$ - Semana Epidemiológica (SE) 05/2016 (31/01 a 06/02/2016). [cited 2016 Feb 12]. Available from: http://portalsaude.saude.gov.br/images/ pdf/2016/fevereiro/12/COES-Microcefalias-Informe-Epidemiologico-12SE-05-2016-12fev2016-13h30.pdf.

8. Protocolo de vigilância e resposta à ocorrência de microcefalia. Available from: www.saude.gov.br/svs.

9. Monitoramento dos casos de microcefalia no Brasil. Informe Epidemiológico $\mathrm{N}^{\circ} 14$ - Semana Epidemiológica (SE) 07/2016 (14/02 a 20/02/2016). [cited $2016 \mathrm{Feb} 24]$. Available from: http://portalsaude.saude.gov.br/images/ pdf/2016/fevereiro/23/coes-microcefalia-informe-epidemiologico14-se072016-fev2016-14.pdf.

10. Centro de Operações de Emergências em Saúde Pública sobre Microcefalias. Monitoramento dos casos de microcefalias no Brasil. Available from: http:// portalsaude.saude.gov.br/images/pdf/2015/novembro/30/coes-microcefalias--informe-epidemiol--gico---se-47.pdf.

11. Brazilian Ministry of Health. Ministério da Saúde investiga 3.852 casos suspeitos de microcefalia no país. [cited 2016 Feb 12]. Available from: http:// portalsaude.saude.gov.br/index.php/cidadao/principal/agencia-saude/22145 ministerio-da-saude-investiga-3-852-casossuspeitos-de-microcefalia-no-pais

12. Pan American Health Organization. Epidemiological alert. Increase in microcephaly in the northeast of Brazil - epidemiological alert. Washington, DC: World Health Organization, Pan American Health Organization, 2015 Available from: http://www.paho.org/hq/index.php?option=com docman\&task=doc_view\&Itemid $=270 \&$ gid $=32636 \&$ lang $=$ en .

13. Pan American Health Organization. Neurological syndrome, congenital malformations, and Zika virus infection. Implications for public health in the Americas - epidemiological alert. Washington, DC: World Health Organization, Pan American Health Organization, 2015. Available from: http://www.paho.org/hq/index.php?option=com_docman\&task=doc_vie w\&Itemid $=270 \&$ gid $=32405 \&$ lang $=$ en .

14. European Centre for Disease Prevention and Control. Rapid risk assessment: microcephaly in Brazil potentially linked to the Zika virus epidemic. Stockholm: European Centre for Disease Prevention and Control, 2015. Available from: http://ecdc.europa.eu/en/publications/Publications/zikamicrocephaly-Brazil-rapid-risk-assessment-Nov-2015.pdf. 
15. CDC. Recognizing, managing, and reporting Zika virus infections in travelers returning from Central America, South America, the Caribbean, and Mexico. CDC Health Advisory. Atlanta: US Department of Health and Human Services, CDC, 2016. Available from: http://emergency.cdc.gov/han/han00385.asp.

16. Calvet G, Aguiar RS, Melo AS, Sampaio SA, de Filippis I, Fabri A, et al Detection and sequencing of $Z$ ika virus from amniotic fluid of fetuses with microcephaly in Brazil: a case study. Lancet Infect Dis. 2016. pii: S1473 3099(16)00095-5.

17. Dick GW. Zika virus. II. Pathogenicity and physical properties. Trans R Soc Trop Med Hyg. 1952; 46(5):521-34.

18. EUROCAT European Surveillance of Congenital Anomalies. Prevalence tables. Ispra, Italy: EUROCAT European Surveillance of Congenital Anomalies; 2015 Available from: http://www.eurocat-network.eu/accessprevalencedata/ prevalencetables.

19. Yoshikawa H. [Epidemiology of Guillain-Barré syndrome]. Brain Nerve. 2015; 67(11):1305-11.

20. Oehler E, Watrin L, Larre P, Leparc-Goffart I, Lastere S, Valour F, et al. Zika virus infection complicated by Guillain-Barré syndrome - case report, French Polynesia, December 2013. Euro Surveill. 2014; 19(9). pii: 20720.

21. Heang V, Yasuda CY, Sovann L, Haddow AD, Travassos da Rosa AP, Tesh RB, et al. Zika virus infection, Cambodia, 2010. Emerg Infect Dis. 2012; 18(2):349-51.

22. Olson JG, Ksiazek TG, Suhandiman, Triwibowo. Zika virus, a cause of fever in Central Java, Indonesia. Trans R Soc Trop Med Hyg. 1981; 75(3):389-93.

23. de Paula Freitas B, de Oliveira Dias JR, Prazeres J, Sacramento GA, Ko AI, Maia $\mathrm{M}$, et al. Ocular findings in infants with microcephaly associated with presumed Zika virus congenital infection in Salvador, Brazil. JAMA Ophthalmol. 2016. [Epub ahead of print]

24. Heang V, Yasuda CY, Sovann L, Haddow AD, Travassos da Rosa AP, Tesh RB, et al. Zika virus infection, Cambodia, 2010. Emerg Infect Dis. 2012; 18(2):349-51.

25. Zammarchi L, Stella G, Mantella A, Bartolozzi D, Tappe D, Günther S, et al. Zika virus infections imported to Italy: clinical, immunological and virological findings, and public health implications. J Clin Virol. 2015; 63:32-5.
26. Cao-Lormeau VM, Roche C, Teissier A, Robin E, Berry AL, Mallet HP, et al. Zika virus, French polynesia, South pacific, 2013. Emerg Infect Dis. 2014; 20(6):1085-6.

27. Mansfield KL, Horton DL, Johnson N, Li L, Barrett AD, Smith DJ, et al. Flavivirusinduced antibody cross-reactivity. J Gen Virol. 2011; 92(Pt 12):2821-9.

28. Scaramozzino N, Crance JM, Jouan A, DeBriel DA, Stoll F, Garin D Comparison of flavivirus universal primer pairs and development of a rapid, highly sensitive heminested reverse transcription-PCR assay for detection of flaviviruses targeted to a conserved region of the NS5 gene sequences. J Clin Microbiol. 2001; 39(5):1922-7.

29. Balm MN, Lee CK, Lee HK, Chiu L, Koay ES, Tang JW. A diagnostic polymerase chain reaction assay for Zika virus. J Med Virol. 2012; 84(9):1501-5.

30. European center for disease prevention and control. [cited $2016 \mathrm{Feb} 19$ ]. Available from: http://ecdc.europa.eu/en/healthtopics/zika_virus_ infection/factsheet-health-professionals/Pages/factsheet_health_ professionals.aspx.

31. Oduyebo T, Petersen EE, Rasmussen SA, Mead PS, Meaney-Delman D, Renquist CM, et al. Update: Interim Guidelines for Health Care Providers Caring for Pregnant Women and Women of Reproductive Age with Possible Zika Virus Exposure - United States, 2016. MMWR Morb Mortal Wkly Rep. 2016; 65(5):122-7.

32. Ventura CV, Maia M, Bravo-Filho V, Góis AL, Belfort R Jr. Zika virus in Brazil and macular atrophy in a child with microcephaly. Lancet. 2016; 387(10015):228.

33. Staples JE, Dziuban EJ, Fischer M, Cragan JD, Rasmussen SA, Cannon MJ, et al. Interim Guidelines for the Evaluation and Testing of Infants with Possible Congenital Zika Virus Infection - United States, 2016. MMWR Morb Mortal Wkly Rep. 2016; 65(3):63-7.

34. Ventura CV, Maia M, Ventura BV, Linden VV, Araújo EB, Ramos RC, et al. Ophthalmological findings in infants with microcephaly and presumable intra-uterus Zika virus infection. Arq Bras Oftalmol. 2016; 79(1):1-3. 